\title{
The New Imbongi: An Oral Poet in South Africa Today - Etienne Van Heerden
}

In South Africa the traditional imbongi or praise poet was very much the voice of the people: the carrier of news, the perpetuator of history. As an oral poet, in the African tradition of oral poetry, he (imbongis were mostly male) would rise at meetings before, for example, the tribal chief spoke, as such operating as mediator between the people and the chief.

Today the role of the oral poet in South Africa is vastly different-and still very much the same. Praise poetry is developing new avenues of expression. Many of the tribal chiefs have lost their credibility and the people, along with their poets, aligned themselves with trade unions and freedom movements such as the African National Congress.

In this role a poet like Alfred Temba Qabula has commanded an audience of more than 60,000 people during a Mandela rally in Soweto, South Africa. Qabula describes his life as follows:

Qabula was born on December 12, 1942 in Flagstaff, Transkei. His father, a migrant worker, "coughed out" the harshness of his life onto his children. He died after his drink was poisoned. Qabula's mother wilted away early in his life, leaving him to look after his brothers.

In 1964 Qabula started working as a plumber. This trade took him to Durban, where, "fed up with doing skilled work for nothing," in 1974 he entered the noisy world of factory production at Dunlop, composing songs in his head as he drove around on a fork-lift truck.

In 1983 he joined the Metal and Allied Workers Union and started to perform his oral poetry at union meetings. His performances initiated a revival of imbongi poetry throughout South Africa, as workers have transformed this tradition into a powerful expression of their struggles.

In 1986 a collection of his poetry was published in Black Mamba Rising, along with the poetry of other worker poets. Qabula has also published $A$ Working Life: Cruel Beyond Belief, 
which was banned in South Africa, but recently unbanned. He has visited France, the Netherlands and paid two visits to the USA, the last time as a member of the International Writing Program.

He now works for the Culture and Working Life Project, Department of Sociology, University of Natal, South Africa.

\section{SOURCES}

Kaschula, R. "Xhosa Oral Poetry: A Changing Tradition." Rhodes Review. 1989.

Qabula, A. T. A Working Life: Cruel Beyond Belief. National Union of Metalworkers of South Africa. 1989. 